\title{
Fifteenth Annual Saskatchewan Christmas Bird Count, 1956
}

\author{
Edited by STUART and MARY HOUSTON
}

In spite of the mildest Christmas season on record, this year only 17 localities reported, the lowest number since 1950. However, a record of 57 species were observed bettering the totals of 53 species in 1955 and 51 species in 1954.

The Magpie was the commonest species, cbserved in all 17 localities. Next was the English Sparrow, from 15; Snow Bunting, from 13; Blacicapped Chickadee, Ruffed Grouse, Sharp-tailed Grouse, from 12; and Pine Grosbeak and Downy Woodpecker from 11. The Horned Owl and Hungarian Partridge were seen in 10 areas, the Hairy Woodpecker in 9 and the Northern Shrike in 8. Thus it was an unusually good year for both Horned Owls and Northern Shrikes. The Ruffed Grouse was well up on the list. Farther down the "Christmas hit parade" were the Bohemian Waxwing and Common Redpoll, seen at only seven places. The Blue Jay, from six districts, and Canada Jay, from only four, were also less common than usual.

Special credit must go to Steve Mann, whose contagious enthusiasm sparked a party of eight cbservers at the rural post office of Skull Creek, south of Piapot. Notice should also be given the Saskatoon Natural History Society, who fielded a record 27 observers and combed their area most thoroughly.

The Regina group had only a short list of the expected winter biras, but had a real field day at the open water near the power house at Wascana Marsh. They recorded 14 species of water birds, and added SEVEN NEW SPECIES to the master list of birds seen in all the 15 Saskatchewan Christmas bird counts-which therefore stands at the fabulous total of 85 species; The new species were: Eared Grebe, Western Grebe, Canvasback, Ruddy Duck, Red-breasted Merganser, Herring Gull and Purple Finch.

The small accipiter, seen by Ed Brooman at Carlton, would have added an additional species to the list, if it could have been positively identified. Other unidentified hawks were a falcon at Dilke (Belcher), a small hawk at Hawarden (Kvinge), a falcon at Carlton (Houston) and two hawks at Yorkton (Chillman and Cursons.)

\section{HISTORICAL STUDY:}

Bird watchers from Yorkton, Saskatoon and Prince Albert converged on the Carlton area, 50 miles north of Saskatoon, on Dec. 30, in order to ccmpare their findings with those cf Sir John Richardson 130 years before.

J. Richardson, M.D., F.R.S., F.L.S. later to become Sir John Richardson, was surgeon, naturalist and secondin-command to the first and second Arctic cverland expeditions of Sir John Franklin. He was the first man to study and report on the birds, mammals, insects, fish, flowers and geology of what is now Saskatchewan He spent the late winter and spring of 1827 at Fort Carlton on the North Saskatchewan River: The specimen he collected, including some new to science, were described in Fauna Boreali Americana, published in 1831

The only species recorded by the 1956 Christmas count that had no been cbserved on the Saskatchewar at some time by Richardson, were those since introduced from Europe the Hungarian Partridge and English Sparrow. (The fresh pheasant track: sten by John Shadick indicated third introduced species was also ir the district.)

Nine species seen on the Saskat chewan by Richardson were not lo cated in our one-day search: Spruc Grouse, Willow Ptarmigan, Hawl Owl, Great Gray Owl, Long-eare Owl (Richardson listed it as winter ing, but this may have been a mis taken assumption), Richardson's $\mathrm{Ou}$ (named after Richardson), Pileate Woodpecker, American Three-toe Woodpecker and the White-winge Crossbill.

This Carlton count was arrange by long-distance telephone only tw days before, but was entered int with great enthusiasm by those cor tacted. They felt that the enjoymer derived more than compensated fo the distance and inconvenience ir volved. 


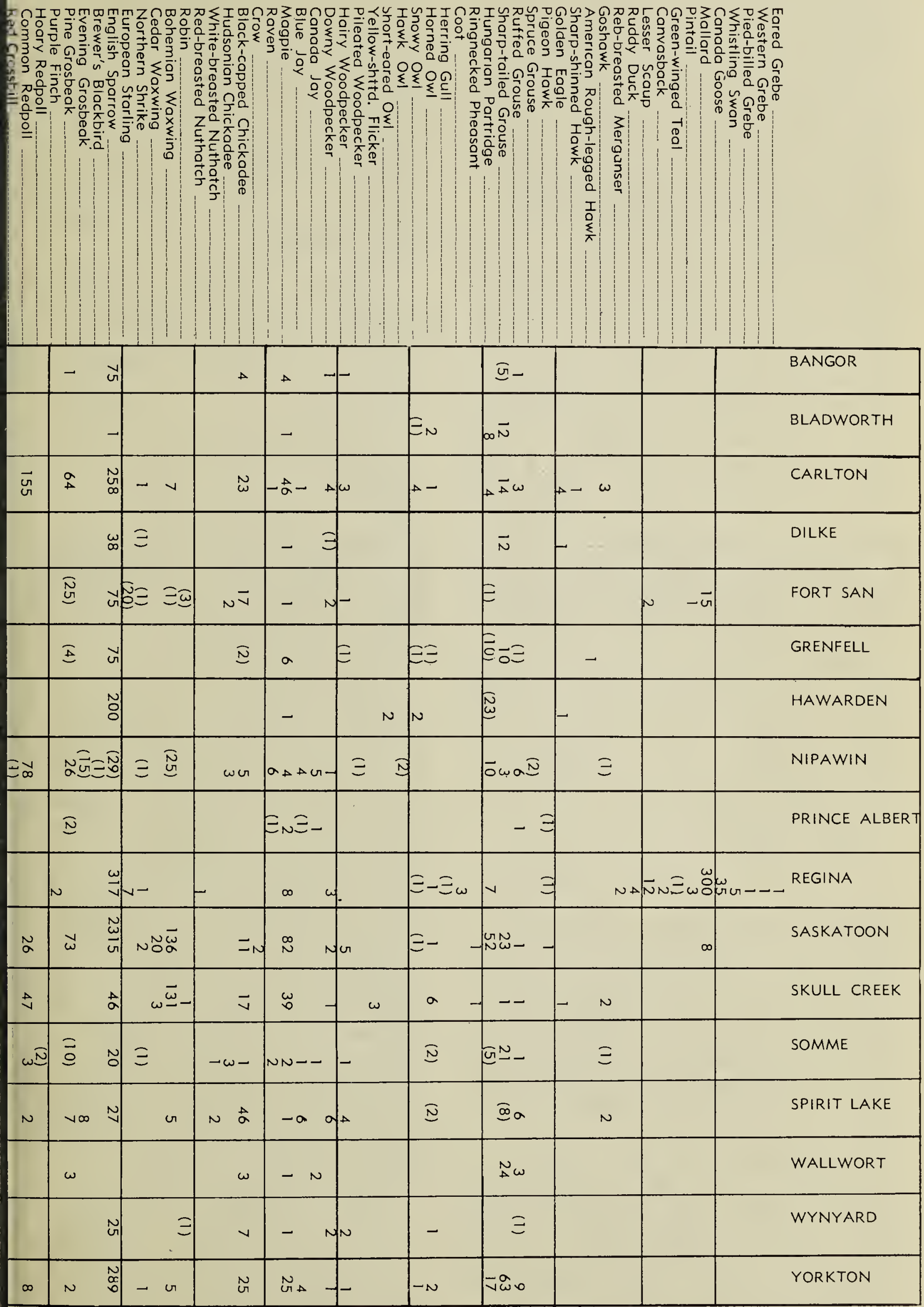




\section{Christmas Bird Count (Continued)}

BANGOR, Dec: 26th. Around the farmyard, and by car 14 miles to Saltcoats. Total, 7 species, 87 individuals, additional 1 species, 5 individuals. Mrs. A. Thompson.

BLADWORTH, Dec. 22. 2 to $4: 30$ p.m.; sunny; temp. 17 to $20^{\circ} ; 8$ inches snow, $2 \frac{1}{2}$ hours, on foot. Total, 5 species. 24 indiv.; add. 2 species, 701 indiv. (Excellent detailed map submitted-Ed.). P. Laurence Beckie.

CARLTON, Dec. 30. 7:30 a.m. to 5 p.m.; mostly sunny; temp. 34 to $38^{\circ}$; wind W, 10 to 20 m.p.h.; 2 to 5 in. snow, 11 observers in 4 parties. Total party hours, 261/2 (13 on foot, $13 \frac{1 / 2}{}$ by car); total party miles, 115 ( 22 on foot, 93 by car). Total, 19 species, 642 indiv. A small accipiter, almost certainly a Sharp-shinned, was noted by Ed Brooman. - Ed. Brooman, Elias Evasiuk, Tony Capusten, Mel Welsh (Prince Albert $\mathrm{Na}$ tural History Society); Jonathan Gerrard, Dr. John Gerrard, J. K. Hogg, J. Frank Roy, John Shadick (Saskatoon Natural History Society); Dr. and Mrs. Stuart Houston (compilers) (Yorkton Natural History Society).

DILKE, Dec. 26. 8 to 12 a.m. and 2 to 4 p.m.; mostly cloudy; temp. 30 to $35^{\circ}$; wind 5 to 20 m.p.h.; 5 inches snow. 4 hours and 3 miles around farm at chores; 2 hours and 2 miles on foot. Total, 4 species, 52 indiv.; add. 3 species, 3 indiv. J. B., S. R. and Margaret Belcher.

FORT SAN, Dec. 23. $1: 15$ to $4: 15$ p.m.; heavily overcast; temp. $16^{\circ}$; calm; 6 in. snow. 3 observers. 24 miles by car. Total, 9 species, 116 indiv.; add. 7 species, 56 indiv. Three Robins Dec. 26 wintering at a spring on the lakeside eight miles west of Fort San. The Brown-capped Chickadees have been at Dr. Fyfe's feeding station daily since Nov. 20 and constitute a new record for this district. Dr. J. G. Fyfe, Jack Lowe, E. M. Callin.

GRENFELL, Dec. 30,11 a.m. to 1 p.m. Clear; temp $30^{\circ}$ to $34^{\circ}$; wind WNW 20 m.p.h.; 12 in. snow. 2 hrs. and 3 miles on ioot; 6 miles by car. Total, 3 species, 91 indiv.; add. 8 species, 21 indiv. An American Rough-legged Hawk seen on Jan. 1. Mr. and Mirs. John Hubbard.

HAWARDEN, Dec. 22, 1:30 p.m. to $4: 30$ p.m., temp. $16^{\circ} ; 4$ in. snow. $9 \frac{1 / 2}{2}$ miles by car, 1 mile on foot. Total, 5 species, 206 indiv.; add. 2 species, 223 indiv. Harold Kvinge.

NIPAWIN, Dec. 27. 9:30 a.m. to 4:30 p.m. Cloudy, temp. $32^{\circ}$; calm; 12 in. snow. 1 hour and 22 miles by car; 6 hours and 10 miles on foot. Total, 12 species, 151 indiv.; add. 11 species, 118 indiv. Two Hawk Owls seen Dec. 31 and one Brewer's Blackbird on Dec. 26. Ann, Walter and Billy Matthews.

PRINCE ALBERT, Dec. 23. 11:45 to $3: 15$. Temp $10^{\circ}$; wind SE 5 m.p.h. 30 miles by car, 2 miles on foot. Total, 4 species, 64 indiv. Add. (on Dec. 26), 4 species, 5 indiv. Tony Capusten.

REGINA, Dec. 26. 147 miles by car; 14 miles on foot. Total, 21 species, 716 indiv. Add: 4 species, 4 indiv. Pigeon Hawk (Richardson's Merlin) noted by Frank. Brazier (Dec. 25), Herring Gull noted by Fred Bard, E. L. and R. Fox (Dec. 30). Fred G. Bard, F. Brazier, W. K. Cruickshank, E L. Fox (compiler), R. Fox, Doug Gilroy, M. Goudie, W. H. Greenberg, Dr. G. F. Ledingham.

SASKATOON, Dec. $26 ， 7: 30$ a.m to $4: 30$ p.m. Sunny, overcast by noon; temp. $35^{\circ}$ to $36^{\circ}$, wind SW 12 m.p.h 27 observers in 6 parties. Total party hours, $35 \frac{1}{2}$ ( 18 on foot, $17 \frac{1}{2}$ by car) total party miles, 228 ( 23 on foot, 205 by car). The Pigeon Hawk was checked by 5 observers; the $8 \mathrm{Mal}$ lards were on the open water below the power-house. Total, 19 species 2811 indiv. Dr. R. M. Bremner, Mr and Mrs. Glen Burgess, R. Burgess Dr. and Mrs. J. Gerrard, Jonathar and Peter Gerrard, George and Ros: Gerrity, Mr. and Mrs. Vic Harper Mi. and Mrs. B. Hinde, Mary Hinde Jim Hogg, J. Moore, Ralph Morris Bob Pravda, Frank Roy, Dr. an! Mrs. L. G. Saunders, John Shadick Dr. E. Wait, R. Wait, H. W. Wicken den, Mrs. M. Younger. (Saskatoo: Natural History Society)

SKULL CREEK, Dec. 30, 8:30 a.m to $1: 30$ p.m. Light clouds, temp. 26 to $40^{\circ}$, wind 15 m.p.h. Five miles o foot along Skull Creek; six miles b car. Total, 16 species, 328 indiv. S. A Mann, Helen Mann, Robert Manr Betty Long, George Swain, Bern Swain, Iris Lyons, Harry William 
SOMME, Dec. 28,9 a.m. to 4 p.m. Calm, temp. $35^{\circ}$, cloudy, 15 in. snow. 3 hours and 20 miles by tractor; 4 hours on foot. Total, 13 species, 1064 indiv., add. 6 species, 21 indiv. Ronald and Donald Hooper.

SPIRIT LAKE, Dec. 30,8 to $5: 30$ p.m. Clear with cloudy intervals; temp. $35^{\circ}$; windy; snow 6 to 20 in. deep. 2 observers separately. $10^{1 / 2}$ hrs. and 9 miles on foot. Total, 15 species, 133 indiv.; add. 2 species, 10 indiv. Bill Anaka, Joyce Gunn.

WALLWORT, Dec. 27. Mild, no wind. Around farm, and 22 miles by car. Total, 7 species, 101 indiv. $\mathbf{J}$. Turnquist.

WYNYARD, Dec. 30 . Total, 6 species, 38 indiv. Add: 2 species, 2 indiv. Robin was noted on Dec. 27.

\section{Bardal}

YORKTON, Dec. 26, 8 a.m. to 5:30 p.m., temp $32^{\circ}$ to $36^{\circ} ; 20$ in. snow. 14 observers in 6 parties. Total party hours, $19 \frac{1 / 2}{2}$ (9 by car, 10 $\frac{1 / 2}{2}$ on foot); Total party miles, 62 (51 by car and 11 on foot). Total, 16 species, 542 ind. Wayne Bjorgan, Brother Clarence, Brother Clement, Henry Chillman, Jr., Ronald Coleman, Tom Cursons, Archie Fraser, Art Gellert, Dr, and Mrs. Stuart Houston, (compilers), Phil Pawluck, Bob Pearce, Cliff Shaw and Jeff Smith. (Yorkton Natural History Society).

MINITONAS, Manitoba, Dec. 22. Around farm. Ruffed Grouse, 4; Blue Jay, 1; Black-capped Chickadee, 4; English Sparrow, 40; White-winged Crossbill, 30. Total, 5 species, 79 indiv. Add: Sharp-tailed Grouse, 1; Magpie, 3; Raven, 3; on additional days. Fay and Will Ranson. (This Manitoba count is not included in the Saskatchewan table following).

\section{Bird Notes}

YELLOW-SHAFTED FLICKER at SASKATOON - Mrs. J. Gerrard reports that none of the usual winter birds have come to their feeding station this winter. However, three times, January 13, 24, 31, they have seen a Yellow-shafted Flicker. come and feed on the shrivelled berries of the Highbush Cranberry and the Virginia Creeper.

SLATE-COLOURED JUNCO WINTERING? - Noted by Dr. L. G. Saunders at Saskatoon on January 30.

IS THE HOODED MERGANSER RARE IN SOUTHERN SASKATCHEWAN? - This quesition is posed by the following report from E. M. Callin, Fort San: "On October 27, 1956 I recorded this bird for only the second time-an apparent indication of its scarcity in the territory which I have been able to cover properly. A well-plumaged male was shot at the head of our group of lakes here and later shown to me. However, a resident at the head of the lakes and who seems to know his game birds very well states that each spring and fall he sees considerable numbers of Hooded Mergansers."

GOLDEN - CROWNED IKINGLET AT YORKTON - Re: Anaka's record of the Golden-crowned Kinglet at Spirit Lake on Oct. 31, 1956 (Blue Jay, XIV, 119), Dr. Stuart Houston,
Yorkton, writes: "This is the fourth record for the Yorkton district-all since publication of The Birds of the Yorktion District (1949). A Goldencrowned Kinglet was found dead on Tupper Ave., Oct. 9, 1951 by Andrew Burant (Blue Jay, IX, Dec., p. 12). I saw two in the Yorkton hospital grounds on Dec. 22, 1953 (Blue Jay, XII, Jan., p. 32). On April 24, 1955, on a Y.N.H.S. outing to Hopkin's Lake on the westerm edge of Yorkton, I located a male in song, and later we observed a female fróm only four feet away. These were likely in migration.

\section{GOLDEN - CROWNED KINGLET} AT FORT QU'APPELLE - On Nov. 2 , 1956, a single bird was seen by E. M. Callin on the Sanitorium grounds. Mr. Callin was attracted by the very high, shrill and somewhat rough quality of the call notes which were uttered insistently, and which he had never heard before. As far as he can recall, Mr. Callin has seen a Golden-crowned Kinglet only once before in the Fort Qu'Appelle area. He notes however, that the Chickadee Notes records two seen on November 5, 1956 (three days later than his own record) by Stanley Harrison of Fort Qu'Appelle. $\mathrm{Mr}$. Harrison found them in his barn where they stayed for about an hour. 